\title{
Pemanfaatan Asap Cair Sabut Kelapa Sebagai Bahan Koagulasi Lateks
}

\section{(Utilization of Coconut Fiber Liquid Smoke as Latex Coagulation)}

\author{
Hesti Hertika Sari Dewi ${ }^{1)}$, Maryanti ${ }^{2)^{*}}$, Febrina Delvitasari ${ }^{2)}$ \\ 1) Program Studi Produksi dan Manajemen Industri Perkebunan, Politeknik Negeri Lampung Jl. \\ Soekarno-Hatta No.10 Rajabasa, Bandar Lampung, 35144, Telp.: (0721) 703995, Fax.: (0721) \\ 787309 dan 2) Jurusan Budidaya Tanaman Perkebunan, Politeknik Negeri Lampung Jl. \\ Soekarno-Hatta No.10 Rajabasa, Bandar Lampung, 35144, Telp.: (0721) 703995, Fax.: (0721) \\ 787309 \\ E-mail:maryanti@polinela.ac.id
}

\begin{abstract}
Smoke liquid for latex coagulant is one of the solution to avoid the negative impact of not recomended coagulant such as vinegar, TSP fertilizer and alum. Coconut fiber has lignin content so that it can be processed into liquid smoke. The aim of this study was to determination the best dose of coconut fiber liquid smoke for latex coagulant and the effect on the quality of SIR product. The treatment used in this study was the dose of coconut coir liquid smoke (formic acid (control) 4.76\% v/v, $13.04 \% \mathrm{v} / \mathrm{v}, 14.89 \% \mathrm{v} / \mathrm{v}, 16.67 \% \mathrm{v} / \mathrm{v}, 18$ $\mathrm{v} / \mathrm{v}, 36 \% \mathrm{v} / \mathrm{v}$, and $20 \% \mathrm{v} / \mathrm{v}$ ). The results showed that the coconut fiber liquid smoke with dose $20 \% \mathrm{v} / \mathrm{v}$ gave the best result on time for clumping latex, total coagulum and total rubber yield. Based on quality data, a dose of $20 \% \mathrm{v} / \mathrm{v}$ include SIR 20 quality.
\end{abstract}

Keywords: coagulation latex, coconut fiber, latex, liquid smoke

DOI: http://dx.doi.org/10.25181/jaip.v7i2.1055

Diterima: 12 Maret 2019 / Disetujui: 9 September 2019 / Diterbitkan: 14 Oktober 2019

\section{PENDAHULUAN}

Indonesia merupakan salah satu negara penghasil karet terbesar di dunia. Perkebunan karet (Havea brasiliensis) memiliki peran yang cukup penting bagi perekonomian Indonesia karena karet merupakan salah satu komoditi ekspor andalan. Ekspor karet Indonesia tahun 2014 mencapai 2,6 juta ton hingga September 2015 ekspor karet Indonesia mencapai angka 2 juta ton (Direktorat Jenderal Perkebunan, 2015).

Secara umum sebagian besar petani karet Indonesia membuat bokar (bahan olahan karet) dari bahan koagulan yang dapat merusak mutu karet seperti cuka para, pupuk TSP, tawas, air perasan gadung, dan nanas. Koagulan tersebut bersifat asam tetapi tidak mempunyai sifat antibakteri dan antioksidan, sehingga memacu berkembangnya bakteri perusak antioksidan alami di dalam bokar. Bakteri pembusuk melakukan biodegradasi protein dalam bokar menjadi amonia dan sulfida yang berbau busuk sehingga menimbulkan polusi udara disekitarnya (Solichin \& Anwar, 2006). Oleh karena itu, agar kualitas bokar yang dihasilkan petani memenuhi syarat SNI 06-2047- 
2002 dan mengurangi polusi udara, maka harus dicari koagulan lateks yang selain bersifat asam juga memiliki fungsi sebagai anti bakteri dan antioksidan. Koagulan yang memenuhi syarat tersebut adalah asap cair, yang mempunyai peranan dalam proses penghambatan bakteri (Darmadji, 1997).

Perkebunan kelapa menghasilkan limbah dari proses budidaya, diantaranya adalah sabut kelapa. Sabut kelapa ini belum digunakan secara maksimal dan baru sebagian saja yang dimanfaatkan untuk bahan bakar. Hal ini disebabkan karena terdapat kandungan tinggi lignin dan selulosa yang tinggi (Sudiarta et al., 2010). Salah satu cara strategis untuk memanfaatkan limbah sabut kelapa adalah dengan mengubah limbah tersebut menjadi asap cair dengan metode pirolisis. Asap cair sabut kelapa memiliki komponen senyawa fenol, alkohol, aldehid, karbonil, keton, dan piridin. Adanya kandungan komponen senyawa-senyawa tersebut menyebabkan sabut kelapa berpotensi untuk dijadikan sebagai bahan baku asap cair (Luditama, 2006). Berdasarkan permasalahan tersebut, penulis meneliti potensi solusi baru dengan memanfaatkan asap hasil pembakaran sabut kelapa menjadi asap cair yang dapat digunakan petani untuk dalam proses koagulasi lateks.

\section{METODE PENELITIAN}

Penelitian dilaksanakan mulai bulan Oktober 2017 s.d Juli 2018 yang terdiri dari tiga tahap. Tahap pertama pembuatan asap cair berbahan sabut kelapa dilaksanakan di unit pirolisis KUPT Politeknik Negeri Lampung. Tahap kedua perlakuan dan pengujian bahan baku lateks dilakukan di Laboratorium Produksi Tanaman Politeknik Negeri Lampung. Tahap ketiga pengujian mutu karet crepe sesuai Standard Indonesian Rubber (SIR) di Laboratorium Analisis Kimia Politeknik Negeri Lampung.

Alat dan bahan yang digunakan pada penelitian ini antara lain: alat pirolisis kapasitas 10 litter, korek api, kayu bakar, sabut kelapa, blower, stopwatch, wadah, buret, pH-meter, pengaduk, beacker glass, saringan 40 mesh, lateks segar, asap cair sabut kelapa, asam formiat 5\%, neraca analitik, buret, wadah labu, erlenmeyer, desikator, pemanas, pemegang saringan, gilingan lateks, neraca, lembar plastik, gunting, penjepit, oven, pemegang labu erlenmeyer, sarung tangan asbes, saringan, botol semprot, pembersih saringan, terpentin mineral, peptiser, slica gel, pembakar listrik, tang, mufe furnace, porselin, desikator, oven, kertas saring, cawan porselin, pengukur tebal, wallace punch, wallacerapi plasticity-meter, tatakan contoh, kertas sigaret, mesin kompa hidrolik, cetakan, piringan komparator lovibond, lembaran tipis poliester transparan atau solulose, dan bingkai komparator. Perlakuan yang diterapkan adalah asap cair sabut kelapa yang terdiri atas enam taraf, yaitu asam formiat 4,76\% sebagai kontrol $\left(\mathrm{K}_{0}\right)$, asap cair sabut kelapa $13,04 \%\left(\mathrm{~K}_{1}\right)$, asap cair sabut kelapa $14,89 \%\left(\mathrm{~K}_{2}\right)$, asap cair sabut kelapa $16,67 \%\left(\mathrm{~K}_{3}\right)$, asap cair sabut kelapa $18,36 \%\left(\mathrm{~K}_{4}\right)$, dan asap cair sabut kelapa $20 \%\left(\mathrm{~K}_{5}\right)$. 
Parameter proses produksi yang diamati adalah lama waktu penggumpalan (menit), rendemen koagulum, rendemen karet, dan $\mathrm{pH}$ penggumpalan. Parameter mutu karet crepe yang diamati mengacu kepada SNI 1903:2011 adalah kadar kotoran, kadar bahan menguap, kadar abu, PRI, dan indeks warna. Data pengamatan dianalisis dengan sidik ragam kemudian dilanjutkan dengan uji beda nyata terkecil (BNT) pada taraf alpha $5 \%$.

\section{HASIL DAN PEMBAHASAN}

\section{Pengaruh Asap Cair Sabut Kelapa terhadap Lama Waktu Penggumpalan}

Tabel 1. Rata-rata lama waktu penggumpalan lateks terhadap setiap perlakuan

\begin{tabular}{clc}
\hline No. & \multicolumn{1}{c}{ Perlakuan } & Lama waktu penggumpalan (menit) \\
\hline 1 & Asap cair sabut kelapa $13,04 \% \mathrm{v} / \mathrm{v}$ & $17,00 \mathrm{a}$ \\
2 & Asap cair sabut kelapa $14,89 \% \mathrm{v} / \mathrm{v}$ & $14,75 \mathrm{~b}$ \\
3 & Asap cair sabut kelapa $16,67 \% \mathrm{v} / \mathrm{v}$ & $12,75 \mathrm{bc}$ \\
4 & Asap cair sabut kelapa $18,36 \% \mathrm{v} / \mathrm{v}$ & $10,75 \mathrm{c}$ \\
5 & Asap cair sabut kelapa $20 \% \mathrm{v} / \mathrm{v}$ & $8,50 \mathrm{~d}$ \\
\hline & Asam formiat kontrol 4,76\% v/v & 13,50 \\
\hline
\end{tabular}

Keterangan: angka pada kolom yang diikuti dengan huruf yang sama menunjukkan tidak berbeda nyata menurut uji BNT 5\%

Berdasarkan hasil penelitian, perlakuan asap cair sabut kelapa dengan dosis yang berbeda berpengaruh terhadap lama waktu penggumpalan. Hasil analisis sidik ragam menunjukkan bahwa penambahan asap cair sabut kelapa berpengaruh nyata terhadap lama waktu penggumpalan dan selanjutnya dilakukan nilai uji tengah menggunakan BNT taraf 5\% $(\alpha=0,05)$.

Hal ini sesuai dengan penelitian yang dilakukan oleh Martrias et al. (2015) yang menyatakan semakin tinggi dosis asap cair arang aktif yang diberikan maka waktu penggumpalan semakin cepat. Selanjutnya Saputra et al. (2016) menyatakan bahwa pemberian dosis asap cair yang rendah waktu penggumpalannya lebih lama dibandingkan dengan pemberian dosis asap cair yang tinggi.

\section{Pengaruh Asap Cair Sabut Kelapa terhadap pH Lateks}

Tabel 2. Rata-rata $\mathrm{pH}$ penggumpalan lateks terhadap setiap perlakuan

\begin{tabular}{clc}
\hline No. & \multicolumn{1}{c}{ Perlakuan } & Nilai $\mathrm{pH}$ \\
\hline 1 & Asap cair sabut kelapa $13,04 \% \mathrm{v} / \mathrm{v}$ & $5,00 \mathrm{a}$ \\
2 & Asap cair sabut kelapa $14,89 \% \mathrm{v} / \mathrm{v}$ & $5,00 \mathrm{a}$ \\
3 & Asap cair sabut kelapa $16,67 \% \mathrm{v} / \mathrm{v}$ & $5,00 \mathrm{a}$ \\
4 & Asap cair sabut kelapa $18,36 \% \mathrm{v} / \mathrm{v}$ & $5,00 \mathrm{a}$ \\
5 & Asap cair sabut kelapa $20 \% \mathrm{v} / \mathrm{v}$ & $5,00 \mathrm{a}$ \\
\hline & Asam formiat kontrol 4,76\% v/v & 3,75 \\
\hline
\end{tabular}

Keterangan: angka pada kolom yang diikuti dengan huruf yang sama menunjukkan tidak berbeda nyata menurut uji BNT 5\% 
Perlakuan asap cair sabut kelapa dengan dosis yang berbeda tidak berpengaruh pada $\mathrm{pH}$ lateks. Hasil analisis sidik ragam menunjukkan bahwa penambahan dosis asap cair sabut kelapa tidak berpengaruh terhadap $\mathrm{pH}$ lateks. Berdasarkan hasil penelitian, $\mathrm{pH}$ asap cair yang dihasilkan berada diatas titik isoelektrik lateks. Menurut Suwardin \& Purbaya (2015), penurunan pH dapat terjadi karena terbentuk asam-asam hasil penguraian oleh bakteri pada lateks atau penambahan asam formiat (asam semut) yang mengakibatkan penurunan $\mathrm{pH}$ sampai ke titik isoelektrik yaitu 4,7 yang menyebabkan partikel karet kehilangan muatannya sehingga lateks akan menggumpal (Tabel 2).

\section{Pengaruh Asap Cair Sabut Kelapa terhadap Rendemen Koagulum dan Rendemen Karet}

Tabel 3. Rata-rata rendemen koagulum terhadap setiap perlakuan

\begin{tabular}{clc}
\hline No. & \multicolumn{1}{c}{ Perlakuan } & Rendemen koagulum (\%) \\
\hline 1 & Asap cair sabut kelapa 13,04\%v/v & $48,91 \mathrm{a}$ \\
2 & Asap cair sabut kelapa 14,89\% v/v & $46,27 \mathrm{a}$ \\
3 & Asap cair sabut kelapa 16,67\% v/v & $45,93 \mathrm{a}$ \\
4 & Asap cair sabut kelapa 18,36\% v/v & $46,77 \mathrm{a}$ \\
5 & Asap cair sabut kelapa 20\% v/v & $49,27 \mathrm{a}$ \\
\hline & Asam formiat kontrol 4,76\% v/v & 45,46 \\
\hline
\end{tabular}

Keterangan: angka pada kolom yang diikuti dengan huruf yang sama menunjukkan tidak berbeda nyata menurut uji BNT 5\%

Hasil analisis sidik ragam menunjukkan bahwa penambahan asap cair sabut kelapa tidak berpengaruh nyata terhadap rendemen koagulum.

Tabel 4. Rata-rata rendemen karet terhadap setiap perlakuan

\begin{tabular}{clc}
\hline No. & Perlakuan & Rendemen karet $(\%)$ \\
\hline 1 & Asap cair sabut kelapa 13,04\%v/v & $31,86 \mathrm{a}$ \\
2 & Asap cair sabut kelapa $14,89 \% \mathrm{v} / \mathrm{v}$ & $31,32 \mathrm{a}$ \\
3 & Asap cair sabut kelapa 16,67\% v/v & $31,41 \mathrm{a}$ \\
4 & Asap cair sabut kelapa 18,36\% v/v & $31,83 \mathrm{a}$ \\
5 & Asap cair sabut kelapa $20 \% \mathrm{v} / \mathrm{v}$ & $32,50 \mathrm{a}$ \\
\hline & Asam formiat kontrol 4,76\% v/v & 33,65 \\
\hline
\end{tabular}

Keterangan: angka pada kolom yang diikuti dengan huruf yang sama menunjukkan tidak berbeda nyata menurut uji BNT 5\%

Berdasarkan hasil penelitian perlakuan asap cair sabut kelapa dengan dosis yang berbeda tidak berpengaruh pada rendemen karet. Hasil analisis sidik ragam menunjukkan bahwa penambahan asap cair sabut kelapa tidak berpengaruh nyata terhadap rendemen karet. Menurut Maryanti \& Edison (2016), hal ini disebabkan karena rendemen karet kering didapat dari hasil proses lebih lanjut rendemen koagulum yang telah melalui proses penggilingan dan pengering anginan, sehingga kandungan air di dalam karet dapat dihilangkan. 


\section{Pengaruh Asap Cair Sabut Kelapa Terhadap Kadar Kotoran}

Tabel 5. Rata-rata kadar kotoran pada setiap perlakuan

\begin{tabular}{clc}
\hline No. & \multicolumn{1}{c}{ Perlakuan } & Kadar kotoran $(\%)$ \\
\hline 1 & Asap cair sabut kelapa $13,04 \% \mathrm{v} / \mathrm{v}$ & $0,043 \mathrm{ab}$ \\
2 & Asap cair sabut kelapa $14,89 \% \mathrm{v} / \mathrm{v}$ & $0,033 \mathrm{~b}$ \\
3 & Asap cair sabut kelapa $16,67 \% \mathrm{v} / \mathrm{v}$ & $0,033 \mathrm{~b}$ \\
4 & Asap cair sabut kelapa $18,36 \% \mathrm{v} / \mathrm{v}$ & $0,053 \mathrm{a}$ \\
5 & Asap cair sabut kelapa $20 \% \mathrm{v} / \mathrm{v}$ & $0,043 \mathrm{ab}$ \\
\hline & Asam formiat kontrol 4,76\% v/v & 0,023 \\
\hline
\end{tabular}

Keterangan: angka pada kolom yang diikuti dengan huruf yang sama menunjukkan tidak berbeda nyata menurut uji BNT 5\%

Kadar kotoran merupakan benda-benda asing atau sejumlah kotoran yang tidak dapat melalui atau yang tertampung pada saringan 325 mesh yang dilarutkan dalam terpentin mineral. Hasil analisis sidik ragam menunjukkan bahwa penambahan asap cair sabut kelapa berpengaruh nyata terhadap kadar kotoran.

Menurut Edison \& Oktara (2014), asap cair masih banyak mengandung lignin, abu, selulosa, dan nitrogen yang dapat meningkatkan kadar kotoran. Adanya kadar kotoran yang tinggi disebabkan oleh adanya zat-zat pengotor yang terkandung dalam karet seperti tanah, batu, pasir, lumpur, daun, tali rotan, batang karet, dan padatan-padatan lainnya yang tidak terlarut.

\section{Pengaruh Asap Cair Sabut Kelapa terhadap Kadar Abu}

Tabel 6. Rata-rata kadar abu pada setiap perlakuan

\begin{tabular}{clc}
\hline No. & \multicolumn{1}{c}{ Perlakuan } & Kadar abu (\%) \\
\hline 1 & Asap cair sabut kelapa 13,04\% v/v & $0,58 \mathrm{a}$ \\
2 & Asap cair sabut kelapa 14,89\% v/v & $0,78 \mathrm{a}$ \\
3 & Asap cair sabut kelapa 16,67\% v/v & $0,78 \mathrm{a}$ \\
4 & Asap cair sabut kelapa 18,36\% v/v & $0,77 \mathrm{a}$ \\
5 & Asap cair sabut kelapa 20\% v/v & $0,72 \mathrm{a}$ \\
\hline & Asam formiat kontrol 4,76\% v/v & 0,88 \\
\hline
\end{tabular}

Keterangan: angka pada kolom yang diikuti dengan huruf yang sama menunjukkan tidak berbeda nyata menurut uji BNT 5\%

Berdasarkan hasil penelitian perlakuan asap cair sabut kelapa dengan dosis asap cair tidak berpengaruh pada kadar abu. Hasil analisis sidik ragam menunjukkan bahwa penambahan asap cair sabut kelapa tidak berpengaruh nyata terhadap kadar abu. Menurut Hidayoko (2014), penentuan kadar abu dimaksudkan untuk melindungi konsumen terhadap penambahan bahan-bahan lain ke dalam karet baik sebelum diolah maupun pada waktu pengolahannya. 


\section{Pengaruh Asap Cair Sabut Kelapa terhadap Kadar Zat Menguap}

Tabel 7. Rata-rata kadar zat menguap terhadap setiap perlakuan

\begin{tabular}{clc}
\hline \multirow{2}{*}{ No. } & \multicolumn{1}{c}{ Perlakuan } & Kadar zat menguap (\%) \\
\hline 1 & Asap cair sabut kelapa $13,04 \% \mathrm{v} / \mathrm{v}$ & $0,65 \mathrm{a}$ \\
2 & Asap cair sabut kelapa $14,89 \% \mathrm{v} / \mathrm{v}$ & $0,55 \mathrm{a}$ \\
3 & Asap cair sabut kelapa $16,67 \% \mathrm{v} / \mathrm{v}$ & $0,45 \mathrm{a}$ \\
4 & Asap cair sabut kelapa $18,36 \% \mathrm{v} / \mathrm{v}$ & $0,59 \mathrm{a}$ \\
5 & Asap cair sabut kelapa $20 \% \mathrm{v} / \mathrm{v}$ & $0,78 \mathrm{a}$ \\
\hline & Asam formiat kontrol 4,76\% v/v & 0,39 \\
\hline
\end{tabular}

Keterangan: angka pada kolom yang diikuti dengan huruf yang sama menunjukkan tidak berbeda nyata menurut uji BNT 5\%

Kadar zat menguap adalah bobot yang hilang dari potongan uji setelah pengeringan. Berdasarkan hasil penelitian perlakuan asap cair sabut kelapa dengan dosis yang berbeda tidak berpengaruh pada kadar zat menguap. Hasil analisis sidik ragam menunjukkan bahwa penambahan asap cair sabut kelapa tidak berpengaruh nyata terhadap kadar zat menguap. Semakin tinggi kadar zat menguap maka semakin rendah mutu produk yang dihasilkan, sebaliknya semakin rendah kadar zat menguap maka semakin tinggi produk yang dihasilkan (Sumarsono et al., 2004).

\section{Pengaruh Asap Cair Sabut Kelapa terhadap PRI (Plasticity Retention Index)}

Tabel 8. Rata-rata PRI terhadap setiap perlakuan

\begin{tabular}{clc}
\hline No. & \multicolumn{1}{c}{ Perlakuan } & Nilai PRI (\%) \\
\hline 1 & Asap cair sabut kelapa 13,04\%v/v & $88,90 \mathrm{a}$ \\
2 & Asap cair sabut kelapa 14,89\% v/v & $88,48 \mathrm{a}$ \\
3 & Asap cair sabut kelapa 16,67\% v/v & $86,70 \mathrm{a}$ \\
4 & Asap cair sabut kelapa 18,36\% v/v & $85,97 \mathrm{a}$ \\
5 & Asap cair sabut kelapa $20 \% \mathrm{v} / \mathrm{v}$ & $85,79 \mathrm{a}$ \\
\hline & Asam formiat kontrol 4,76\% v/v & 94,49 \\
\hline
\end{tabular}

Keterangan: angka pada kolom yang diikuti dengan huruf yang sama menunjukkan tidak berbeda nyata menurut uji BNT 5\%

PRI adalah suatu ukuran yang dapat digunakan sebagai indikator ketahanan karet terhadap degradasi akibat oksidasi pada suhu tinggi. Berdasarkan hasil penelitian perlakuan asap cair sabut kelapa dengan dosis yang berbeda tidak berpengaruh pada PRI. Hasil analisis sidik ragam menunjukkan bahwa penambahan asap cair sabut kelapa tidak berpengaruh nyata terhadap PRI. Menurut Wazyka (2000), senyawa fenol dan turunannya dapat berfungsi sebagai antioksidan yang akan melindungi molekul karet dari oksidasi pada suhu tinggi sehingga nilai PRI akan tetap tinggi. 


\section{Pengaruh Asap Cair Sabut Kelapa Terhadap Indeks Warna}

Tabel 9. Hasil uji indeks warna

\begin{tabular}{clc}
\hline No. & \multicolumn{1}{c}{ Perlakuan } & Indeks earna \\
\hline 1 & Asap cair sabut kelapa 13,04\% v/v & $8,00 \mathrm{a}$ \\
2 & Asap cair sabut kelapa $14,89 \% \mathrm{v} / \mathrm{v}$ & $8,00 \mathrm{a}$ \\
3 & Asap cair sabut kelapa $16,67 \% \mathrm{v} / \mathrm{v}$ & $7,75 \mathrm{a}$ \\
4 & Asap cair sabut kelapa $18,36 \% \mathrm{v} / \mathrm{v}$ & $8,00 \mathrm{a}$ \\
5 & Asap cair sabut kelapa $20 \% \mathrm{v} / \mathrm{v}$ & $8,25 \mathrm{a}$ \\
\hline & Asam formiat kontrol 4,76\% v/v & 6,75 \\
\hline
\end{tabular}

Keterangan: angka pada kolom yang diikuti dengan huruf yang sama menunjukkan tidak berbeda nyata menurut uji BNT 5\%

Berdasarkan hasil penelitian perlakuan asap cair sabut kelapa dengan dosis yang berbeda tidak berpengaruh pada indeks warna. Menurut Telaumbanua et al. (2013), warna hitam dan hitam kecoklatan dari koagulum disebabkan oleh senyawa organik di dalam asap cair, residu asap cair, dan destilat asap cair, baik senyawa yang mudah menguap maupun senyawa fenolik beserta turunannya.

\section{Penentuan Mutu Karet}

Tabel 10. Penentuan mutu karet

\begin{tabular}{|c|c|c|c|c|c|c|c|c|c|c|}
\hline Perlakuan & $\begin{array}{c}\text { Lama } \\
\text { waktu } \\
\text { penggu } \\
\text { mpalan } \\
\text { (menit) }\end{array}$ & $\begin{array}{c}\mathrm{pH} \\
\text { penggu } \\
\text { mpalan }\end{array}$ & $\begin{array}{c}\text { Rendem } \\
\text { en } \\
\text { koagulu } \\
\mathrm{m}(\%)\end{array}$ & $\begin{array}{c}\text { Rendem } \\
\text { en karet } \\
(\%)\end{array}$ & $\begin{array}{l}\text { Kadar } \\
\text { kotoran } \\
(\%)\end{array}$ & $\begin{array}{c}\text { Kadar } \\
\text { abu }(\%)\end{array}$ & $\begin{array}{c}\text { Kadar } \\
\text { zat } \\
\text { mengua } \\
\text { p }(\%)\end{array}$ & $\begin{array}{l}\text { PRI } \\
(\%)\end{array}$ & Indeks warna & SIR \\
\hline $\begin{array}{c}\mathrm{K}_{1} \\
13,04 \%\end{array}$ & 17,00 & 5,00 & 48,91 & 31,86 & 0,043 & 0,58 & 0,65 & 88,90 & $\begin{array}{c}\text { Tidak } \\
\text { memenuhi } \\
\text { kriteria SIR 3L }\end{array}$ & $\begin{array}{c}\text { SIR } \\
20\end{array}$ \\
\hline $\begin{array}{c}\mathrm{K}_{2} \\
14,89 \%\end{array}$ & 14,75 & 5,00 & 46,27 & 31,32 & 0,033 & 0,78 & 0,55 & 88,48 & $\begin{array}{c}\text { Tidak } \\
\text { memenuhi } \\
\text { kriteria SIR 3L }\end{array}$ & $\begin{array}{c}\text { SIR } \\
20\end{array}$ \\
\hline $\begin{array}{c}\mathrm{K}_{3} \\
16,67 \%\end{array}$ & 12,75 & 5,00 & 45,93 & 31,41 & 0,033 & 0,78 & 0,45 & 86,70 & $\begin{array}{c}\text { Tidak } \\
\text { memenuhi } \\
\text { kriteria SIR 3L }\end{array}$ & $\begin{array}{c}\text { SIR } \\
20\end{array}$ \\
\hline $\begin{array}{c}\mathrm{K}_{4} \\
18,36 \%\end{array}$ & 10,75 & 5,00 & 46,77 & 31,83 & 0,053 & 0,77 & 0,59 & 85,97 & $\begin{array}{c}\text { Tidak } \\
\text { memenuhi } \\
\text { kriteria SIR 3L }\end{array}$ & $\begin{array}{c}\text { SIR } \\
20\end{array}$ \\
\hline $\begin{array}{c}\mathrm{K}_{5} \\
20 \%\end{array}$ & 8,50 & 5,00 & 49,27 & 32,50 & 0,043 & 0,72 & 0,78 & 85,79 & $\begin{array}{c}\text { Tidak } \\
\text { memenuhi } \\
\text { kriteria SIR 3L }\end{array}$ & $\begin{array}{c}\text { SIR } \\
20\end{array}$ \\
\hline $\begin{array}{c}\mathrm{K}_{0} \\
\text { Kontrol }\end{array}$ & 13,50 & 3,75 & 45,46 & 33,65 & 0,023 & 0,88 & 0,39 & 94,49 & $\begin{array}{c}\text { Tidak } \\
\text { memenuhi } \\
\text { kriteria SIR 3L }\end{array}$ & $\begin{array}{c}\text { SIR } \\
20\end{array}$ \\
\hline
\end{tabular}

Hasil pengujian mutu yang tersaji pada Tabel 10 menunjukkan bahwa pada perlakuan asam formiat dan asap cair memiliki kriteria SIR 20. 


\section{KESIMPULAN DAN SARAN}

\section{Kesimpulan}

Dari hasil penelitian dapat disimpulkan bahwa asap cair sabut kelapa $20 \%$ v/v baik untuk dijadikan sebagai bahan koagulasi lateks dan dosis asap cair sabut kelapa $20 \%$ v/v menghasilkan mutu SIR 20 dengan nilai mutu kadar kotoran 0,043\%, kadar abu 0,72\%, kadar zat menguap 0,78\%, dan PRI 85,79\% dan dari kriteria warna, hasil penelitian tidak memenuhi mutu SIR (Standard Indonesian Rubber) SNI 1903:2011

\section{Saran}

Asap cair sabut kelapa dapat dijadikan sebagai bahan koagulasi lateks, dan perlu dilakukan penelitian lebih lanjut mengenai penyulingan (pre treament) pada asap cair sabut kelapa sehingga karet krep yang dihasilkan mendapatkan mutu yang lebih tinggi dari SIR 20.

\section{DAFTAR PUSTAKA}

Darmadji, P. (1997). Aktivitas antibakteri asap cair yang diproduksi dari bermacam-macam limbah pertanian. Agritech, 16(4), 19-22.

Direktorat Jendral Perkebunan. (2015). Statistika Perkebunan Indonesia 2014-2016. Kementerian Pertanian Republik Indonesia. Jakarta.

Edison, R. \& Oktara, H. (2014). Aplikasi Asap Cair dan Arang Hitam Hasil Pirolisis Tempurung Kelapa dalam Produksi Karet. Politeknik Negeri Lampung. Bandar Lampung

Hidayoko, G. \& Wulandra, O. (2014). Pengaruh Penggunaan Jenis Bahan Penggumpal Lateks Terhadap Mutu SIR 20. Program studi Teknologi Pertanian. Fakultas Pertanian. UNIVED Bengkulu. Bengkulu.

Luditama, C. (2006). Isolasi Dan Pemurnian Asap Cair Berbahan Dasar Tempurung Dan Sabut Kelapa Secara Pirolisis Dan Distilasi. Fakultas Teknologi Pertanian. Institut Pertanian Bogor, Bogor.

Maryanti, \& Edison, R. (2016). Pengaruh dosis serum lateks terhadap koagulasi lateks (Hevea brasiliensis). Jurnal Agro Industri Perkebunan, 4(1), 54-59.

Matrias, D., Edison, R., \& Supriyatdi, D. (2015). Penggunaan asap cair dan arang aktif tempurung kelapa pada mutu karet krep. Jurnal Agro Industri Perkebunan, 3(1), 1-10.

Saputra, Ersan, \& Rofiq. M. (2016). Pengaruh asap cair berbahan baku pelepah kelapa sawit sebagai koagulan pada kualitas karet krep. Jurnal Agro Industri Perkebunan, 4(1): 41-53.

Sudiarta, I. W., \& Yulihastuti, D. A. (2010). Biosorpsi kromium pada serat sabut kelapa hijau (Cocos nucifera). Jurnal Kimia, 4(2), 158-166. 
Sumarsono, Zuki, M, \& Darlenawati. (2004). Analisis mutu karet remah sir 20 berdasarkan kombinasi komposisi bahan baku di PTPN VII (Persero) Unit Usaha Padang Pelawi, Bengkulu Selatan. Jurnal Penelitian UNIB, 10(2), 86-91.

Suwardin, D. \& Purbaya, M. (2015). Jenis bahan penggumpal dan pengaruhnya terhadap parameter mutu karet spesifikasi teknis. Jurnal Warta Perkaretan, 34(2), 147-160.

Telaumbanua, Z., Wirjosentono, B., \& Eddiyanto. (2013). Pemanfaatan asap cair dari tempurung kelapa sebagai koagulan komersial karet alam Nias Utara. Jurnal Teknologi Kimia Unimal, $2(2), 55-67$.

Wazyka, A. (2000). Aktivitas Antioksidan Asap Cair Kayu Karet dan Redistilatnya terhadap Asam Linoleat dan Poliisopropen. Unpublished graduate student. Program Studi Ilmu dan Teknologi Pangan, Jurusan Ilmu Pertanian, Program Pasca Sarjana Universitas Gadjah Mada. Yogyakarta. 